\title{
Shade Cum Fruit Yielding Avocado Under Coffee Ecosystem
}

\author{
M. Govindappa ${ }^{1, \star}$, K. Elavarasan ${ }^{2}$ \\ ${ }^{1}$ Department of Agronomy, Agronomist, Govt. of India, Regional Coffee Research Station, \\ Coffee Board, Thandgudi - 624216, India \\ ${ }^{2}$ Extension Inspector, Govt. of India, Regional Coffee Research Station, Coffee Board, \\ Thandgudi - 624216, India \\ *E-mail address: smsagron@gmail.com , princekau@gmail.com
}

\begin{abstract}
Avocado is one of the most commonly preferred shades grown tree crop under Coffee ecosystem. In view of that, Peninsula of Nicoya and Cost Rica farmer was rated avocado (Persea americana L. Mill) is a primary shade tree crop under coffee plantation at the level of 66.3 per cent and it ranked as a fourth position after the Inga spp., Guazumala ulmiflora and Cardia alliodoara. Hence, the avocado is a commercially important shade cum fruit yielding tree under coffee ecosystem which has cultivating both in humid tropic as well as subtropical climates of throughout the world. The tree is basically grown as the forest species but later on as a shade growing tree under coffee cultivation because of high nutritional and medicinal values of fruit and it makes for wider diversity. Thereafter it was entered into the other parts of the world from Central America and Mexico. The tree is of multipurpose in nature and also helps to avoid the soil and water erosion by way of its wider spread canopy. Generally, Avocado leafs reduce the beating action of rain drops which in-turn minimize the soil erosion. The soil enrichment by adding the leaf litter continuously is an advantage in the coffee plantations. It yields in the additional economic returns after three to five years of establishment. Hence, the establishment of shade tree under coffee ecosystem will give additional income to the coffee growers, which mainly helps on lean period of coffee cultivation.
\end{abstract}

Keywords: Shade cum fruit tree; additional income; nutrition; anti-cholesterol; economic benefit

\section{INTRODUCTION}

The word "Avocado" has been derived from the Spanish word "ahuacatl" which means the "testical" due to its shape. The avocado (Persea americana Mill) botanically belongs to family of Lauracea. The tree was originated from Southern Mexico and Central America (Human, 1987). The tree grows up to the height of 20-22 meters (65-72 feet) with alternatively arranged leaves. The length and width of leaves varies between 12-25 centimeters and 5-10 centimeters respectively. The flowers are very minute and they are protogyny in nature. i.e. the female flowers mature early then the males. Hence it is highly cross-pollinated in nature. The size of the flowers varies from $5 \mathrm{~mm}$ to $10 \mathrm{~mm}$. The fruit is pear shaped and the length varies from $7-20 \mathrm{~cm}$ and the width varies from $5-15 \mathrm{~cm}$. The weight of the fruit varies from 300 grams to 1000 grams and it has only one single seed which measures about 4-6 cm length (Albertin and Nair, 2004). 
According to Ghosh (2000) avocado is still a minor fruit crop in India. It was introduced from Sri Lanka in the early parts of the $20^{\text {th }}$ century and presently it is cultivated in a scattered way in tropical south Indian states like Tamil Nadu, Kerala, Karnataka and Maharashtra. The crop is also popular in the north eastern Himalayan state Sikkim, where it is grown successfully on hill slopes at an elevation range of 800-1,600 m. Climatically, it is grown both in tropical areas experiencing summer rains and in humid sub-tropics with mild winter. The range of mean maximum and minimum temperature in the Niligiri Hills of Tamil Nadu (South India) where avocado is grown is $27.2{ }^{\circ} \mathrm{C}$ to $33.9{ }^{\circ} \mathrm{C}$ and $14.9{ }^{\circ} \mathrm{C}$ to $22.2{ }^{\circ} \mathrm{C}$, respectively. In the north eastern state Sikkim the avocado growing area experiences temperature range from $12{ }^{\circ} \mathrm{C}$ to $30^{\circ} \mathrm{C}$ with average rainfall of $2,000 \mathrm{~mm}$.

All three horticultural races namely West Indian, Guatemalan and Mexican have been tried in India and the varieties Fuerte, Hass and Green performed well at different places. The harvesting season of fruit is from July to September and a tree of 10-15 years old produces 300-350 fruits per year. Vegetative propagation is still not a common practice, and in Sikkim all the trees are of seedling origin. There is no serious plant protection problem experienced so far and with a little technological support avocado can come up well in India.

The avocado is a native of Tropical America and it was originated from the Mexico and Central America since from 700BC. It was well distributed in both the tropical, sub-tropical and Mediterranean climates of the world. Its cultivation was recorded by the earlier Spanish researchers and they revealed that the practice of avocado cultivation was spread from Mexico to Peru and it was introduced to Jamaica in 1650. It was noted that it was introduced to Florida, California and Zanzibar during 1833, 1856 and 1892 respectively. Now this shade cum fruit yielding tress was being cultivated in many of the countries which includes The Mexico, Chili, Dominican Republic, Indonesia, United States of America, Columbia, Peru, Kenya, Brazil Rwanda, and China. The avocado was introduced to India from Srilanka in the early part of the $20^{\text {th }}$ centaury. In India it is being cultivate at small scale and the important states include the Tamil Nadu, Kerala and Karnataka and Maharashtra. It is also cultivated in the small scales in the parts of south central India and in the eastern Himalayan state of Sikkim.

\section{AGRONOMY OF AVOCADO}

\section{a. Climatic Features:}

The avocado plant is well adapted to wide range of climatic features and it comes well in the areas of humid tropic and subtropical regions of the World. It perform well in altitudes ranging between 800 to 1200 meters and annual average rainfall requirement of the crop is varies from $900 \mathrm{~mm}$ to $1200 \mathrm{~mm}$. But, the plant cannot tolerate extreme cold, very high temperature, high wind speed and more frost conditions during the different growth stages of critical period. The flowers are very sensitive when it reaching very low and freezing temperatures. The optimum temperature ranges between $14-32{ }^{\circ} \mathrm{C}$. Normally, plant prefers more sunshine hours which directly influence the optimum productivity crop as well as more TSS content with high mineral composition. (Woolf et al., 1999)

b. Soil type:

The avocado plant tolerates in both acidic and alkaline conditions to some extent but it does not tolerate the saline conditions. It performs well in well drained sandy loam and aerated soils. It is highly susceptible for water logged conditions Hence well drained soil like hill side laterite soils are best suitable for its cultivation. 
c. Soil Ph:

The avocado do no tolerates the water logged and marshy conditions .it also do not withstand in the saline conditions. The optimum range of soil $\mathrm{pH}$ required by the plant is between 5-7.

d. Nutrition:

The availability of residual organic carbon and the external application synthetic fertilizers like N, P.K during the early stages of the crop will enhances the better vegetative growth and it promotes in the well establishment of the seedlings in the field.

e. Important Verities and their features:

The avocado tree species has wide range of species which are cultivating in the world. But among them the most important are three species which include 1. Mexican, Guatemala and the West Indies. The main difference and the important different characteristic features of these species are provided in the Table 1.

Table 1. The difference between three important Avocado species.

\begin{tabular}{|c|c|c|c|c|}
\hline \multirow{2}{*}{$\begin{array}{c}\text { Main } \\
\text { attributes }\end{array}$} & Specific attributes & \multicolumn{3}{|c|}{ Properties by varieties } \\
\cline { 3 - 5 } & Size & Mexican & Guatemala & West Indian \\
\hline \multirow{2}{*}{ Seed } & Cavity & Loose & Tight & Big \\
\cline { 2 - 5 } & Size & Small & Various & Various \\
\hline \multirow{2}{*}{ Leaf } & Skin & Thin & Worthy & Warty \\
\cline { 2 - 5 } & Oil content & High & Medium & Low \\
\cline { 2 - 5 } & Maturity in month & 6 & 9 & 6 \\
\hline \multirow{2}{*}{ Oil } & Scent & Nice & None & None \\
\hline \multirow{2}{*}{ Tolerance } & Cold & Tolerant & In -Tolerant & In-Tolerant \\
\cline { 2 - 5 } & Salt & In -Tolerant & In -Tolerant & In-Tolerant \\
\hline
\end{tabular}

\section{1. Roles of avocado in coffee ecosystem}

Recent coffee varieties can obtain higher yields when grown under full sun in optimal environmental conditions under Brazil situation whereas in India production is benefited by cultivation of Avocado as shade trees under sub-optimal conditions (Muschler, 2000). Optimal conditions for coffee growth include elevations of 1200 to 1700 MSL, mean annual 
temperatures ranging from 17 to $23{ }^{\circ} \mathrm{C}$, mean annual precipitation ranging from 1500 up to $2800 \mathrm{~mm}$ and fertile volcanic or alluvial soils but this condition privilege only Brazil condition not in India (ICAFE, 1998). The advantages of using Avocado as shade trees, especially under suboptimal conditions for coffee, include both climate and site amelioration, such as buffering temperature extremes in the air and soil and maintaining soil fertility through the incorporation of organic matter from leaf litter and prunings (Beer et al., 1998). Also, by regulating light transmission to coffee plants - which regulates coffee yields - shade trees can also extend the life of the coffee plantation (Beer, 1987). Staver et al. (2001) found that in a low-elevation, dry coffee zone, the use of 35 to $65 \%$ shade promoted leaf retention in coffee plants during the dry season and reduced the incidence of disease-causing fungi such as Cercospora coffeicola and Planococcus citri, without reducing yields or increasing the incidence of coffee rust disease, Hemileia vastatrix.

Other benefits of shading included an increase in the effectiveness of microbial and parasitic organisms and a reduced quantity of weeds. Similarly, in a study conducted in the Atlantic region of Costa Rica, Muschler (1997) found that the use of the tree Erythrina poeppigiana at shading densities of 20 to $60 \%$ resulted in improved vegetative growth and yield in robust coffee berries and also will reduced incidence of weeds in the stand. Denser shading resulted in lower yields and lower fruit quality viz verse under fully open condition similar effect could be recorded.

\section{ADVANTAGES BY THE CULTIVATION OF AVOCADO IN THE COFFEE PLANTATION}

1. Avocado is of multipurpose in nature hence it provides the permanent shade to the growing Coffee and promotes better seedling establishment by avoiding direct sunlight and sun scorching effect

2. It helps in the maintenance of the Coffee quality

3. It provides fuel and fruits which are economically have high value in both world and national market

4. It protects the soil from direct beating action of the rain drops so as it reduces the acceleration of the soil erosion and how it prevents top fertile soil

5. Avocado trees serves as the home for many kinds of birds and so it adds the improvement of bio-diversity of the Coffee plantations

6. The shedding of leaf-litter adds as the good source of organic manure and it in-turn reduces the soil temperature congenial for better growth and development

7. The fruits of Avocado are considered as the functional food by the modern food processing industries which in-turn adds the economic revenue to the national GDP

8. The avocado oil and its nutrient components are the good raw materials of both cosmetic and Pharmaceutical industries

9. The cost of cultivation is very low and the fruit produce was adds to the net profit and hence economic gain are more with low or zero investment.

10. Low incidence of pest and diseases hence the no need of spraying of plant protection chemicals and it adds the conservation of environment and no pollution. 


\section{DISADVANTAGES BY THE CULTIVATION OF AVOCADO IN THE COFFEE PLANTATION}

1. Disadvantage of the use of trees in agroforestry systems is competition with the associated crop (Beer et al., 1998) and this varies according to climate, soils, management practices and species (Rao et al., 1998).

2. Using Avocado as shade trees are reduced the crop yields due to overshading

3. Higher incidence of fungal attacks by Mycena citricolor due to increased humidity in the coffee ecosystem

4. The possibility of allelopathic effects between coffee and particular shade tree species (Beer, 1987).

\section{CONCLUSION}

The avocado fruit trees is one of the best shade cum fruit yielding tree which was cultivating in all the tropical, sub-tropical and Mediterranean climates of the world. Since it come up-well in all types of soil exempt waterlogged and marshy soil, there is much scope for the cultivation of avocado in the regions of cool and moderate temperature with well drained soils like Western Ghats, Eastern Ghats, foot hills of northern Himalayas and NorthEast regions where coffee is being cultivating. The most potential states of India are Karnataka, Kerala and Tamil Nadu and also some parts of Sikkim etc. Since the world and national marked is demanding for the production of various health related cosmetics and pharmaceuticals there is need to expand it in the non-cultivated arable lands, As it produces the additional economic yield to the grower.

\section{References}

[1] Albertin A., Nair P.K.R., Human ecology 32(4) (2004).

[2] Beer J., Agroforestry Systems 5 (1987) 3-13.

[3] Beer J., Muschler R., Kass D., Somarriba E., Agroforestry Systems 38 (1998) 139-164.

[4] Ghosh S.P. (2000). Avocado production in India. In: Papadimetrious, M.K (ed.). Avocado production Asia and the Pacific. FAO publisher, Bangkok, pp. 24-30.

[5] Human T.P. (1987). Oil as a byproduct of the avocado. South African Avocado manual of tropical and subtropical fruits excluding the banana,coconut, pineapple citrus fruits, olive and fig, wilson popenoe Agricultural Explorer, United States Department of Agriculture

[6] Woolf A.B., Ferguson I.B., Requejo-Tapia L.C., Boyd L., White A., Revista Chapings Serie Horticultura 5 (1999) 353-358.

[7] ICAFE (1998). Manual de Recomendaciones para el cultivo de caf'e, ICAFE-CICAFE, Heredia, Costa Rica.

[8] Muschler R.G. (1997). Effects of shading by Erythrina poeppigiana on Coffea arabica cvs. Caturra and cv. Catimor. In Memorias del XVIII Simposio Latinoamericano de Caficultura, San Jose, Costa Rica, IICA, San Jose, Costa Rica, pp. 157-162. 
[9] Muschler R. G. 2000. Arboles en Cafetales. Modulo de Ensenanza Agroforestal, Proyecto Agroforestal CATIE/GTZ, CATIE, Turrialba, Costa Rica, p. 5.

[10] Rao M. R., Nair P. K. R., Ong C. K., Agroforestry Systems 38 (1998) 3-50.

[11] Staver C., Guharay F., Monterroso D., Muschler R. G., Beer J., Agroforestry Systems 53 (2001) 151-170. 